\title{
KURVA PERTAMBAHAN BOBOT BADAN DOMBA GARUT JANTAN 13-16 BULAN DIBERI 80\% HIJAUAN DAN 20 \% KONSENTRAT
}

\section{(Body Weight Growth Curve of Male Garut Sheep 13-16 Months Fed 80\% Forage and 20\% Concentrate)}

\section{Naufal Raihan', Dedi Rahmat ${ }^{1}$, Budi Ayuningsih', Fransiskus Teguh Santoso², Tidi Dhalika ${ }^{1}$ dan Iman Hernaman ${ }^{1}$}

${ }^{1}$ Fakultas Peternakan Universitas Padjadjaran, Sumedang, 45363

${ }^{2}$ Unit Pelaksan Teknis Dinas (UPTD) Balai Pengembangan dan Perbibitan Ternak Domba dan Kambing (BPPTDK) Margaw ati, Garut, 44113

Penulis Koresponden: iman_hernaman@yahoo.com

Article Submitted: 09-07-2021

Article Accepted:

\section{ABSTRACT}

The research was carried out at the UPTD of the Margawati Sheep and Goat Breeding Center, the Department of Food Security and Livestock of West Java Province with the aim of finding a body weight gain curve model for Garut sheep. Eight male Garut sheep aged 13-16 months were reared for 12 weeks and given a ration with a composition of $80 \%$ forage and $20 \%$ concentrate. The sheep were measured and weighed every week during the study to obtain data on body weight gain. The collected data were analyzed using Curve Expert. The results showed that body weight gain increased until week 10 and then decreased until week 12 forming a curve. The Polynomial model curve gives the best curve with the equation $=2.61+9.53 \mathrm{X}$ $3.50 X^{2}+0.676 X^{3}-0.03 X^{4}$ and has a standard error value (SE) of 7.27 and a coefficient of determination $(\mathrm{R} 2)$ of 0.94 .

Keywords: body weight gain, concentrate, forage, male Garut sheep, non-linear regression

\section{PENDAHULUAN}

Domba Garut adalah domba asli Indonesia dengan ciri-ciri khusus yaitu memiliki ekor ngabuntut beurit atau ngabuntut bagong atau kombinasinya dengan bentuk telinga yang rumpung $(<4$ $\mathrm{cm})$ atau ngadaun hiris $(4-8 \mathrm{~cm})$ (Heriyadi \& Surya, 2004). Domba ini cepat beradaptasi dengan lingkungannya dan memiliki produktivitas yang tinggi. Selain itu, sangat erat dengan budaya dan menunjang pendapatan serta perekonomian masyarakat di Jawa Barat (Anang, Dudi, Indrijani, \& Rahmat, 2013). Terdapat 2 tujuan pemeliharaan Domba Garut di masyarakat, yaitu dipelihara untuk menghasilkan daging (tipe pedaging) dan sebagian peternak memeliharanya untuk ternak fancy (Haya, Anang, \& Heriyadi, 2020).

Pemeliharaan ternak dimulai dari saat lahir sampai dewasa dengan berbagai tujuan yang diharapkan dan pada hakekatnya pemeliharaan tersebut adalah untuk mencapai pertumbuhan ternak yang optimal. Pertumbuhan meliputi pertambahan bobot badan disertai dengan perubahan komposisi tubuhnya termasuk organ jaringan dan komponennya pada fase pertumbuhan yang berbeda. Pertambahan bobot badan (PBB) merupakan indicator dalam menilai laju pertumbuhan dari suatu ternak (Anang, 
Dudi, Indrijani, \& Rahmat, 2013). Faktor yang sangat mempengaruhi pertumbuhan ternak adalah genetik dan lingkungan, pada kondisi yang ideal bobot badan akan memperlihatkan laju pertumbuhan lebih besar sebelum mencapai pubertas dan semakin lambat saat menjelang dan telah mencapai dewasa tubuh (Rusdiana \& Adiati, 2020). Pertambahan bobot badan secara ideal mengikuti pola kurva huruf S (sigmoideal atau S-shaped), laju pertambahan bobot badan mula-mula lambat, kemudian berlangsung cepat, lalu melambat dan terhenti setelah mencapai tingkat kedewasaan (Urfa, Indrijani \& Tanwiriah, 2017).

Gambaran kemampuan suatu ternak dalam menampilkan potensi genetik serta sebagai hasil dari berkembangnya bagianbagian tubuh hingga ukuran dewasa dapat dilihat dari kurva pertambahan bobot badannya. Kurva ini berupa kurva regresi linier atau non-linier. Akan tetapi kurva regresi linier memiliki kelemahan karena akan memberikan penafsiran yang salah pada saat laju pertumbuhan melandai terutama setelah titik infleksi. Untuk mengatasi kelemahan tersebut digunakan kurva regresi non-linier (Salman, Noor, Saefuddin \& Talib, 2012; Putra, Sumadi, Hartatik. \& Saumar, 2018) agar dapat menjelaskan keterkaitan antara pertumbuhan ternak dengan waktu pemeliharaan, sehingga masalah fenomena secara biologis dapat teratasi.

Pertambahan bobot badan domba sangat dipengaruhi oleh jumlah dan kualitas ransum, hal ini berarti bahwa pertambahan bobot badan domba akan sejalan dengan ransum yang dikonsumsi (Ayuningsih, Hernaman, Ramdani, \& Siswoyo, 2018). Pertambahan bobot badan dipengaruhi beberapa faktor yaitu total protein yang diperoleh setiap harinya, jenis kelamin, umur, tipe kelahiran, keadaan genetis lingkungan, kondisi setiap individu, dan manajemen tata laksana (National Research Council, 2006).

Pakan ruminansia terdiri atas pakan utama, yaitu hijauan dan bila pakan utama belum memenuhi kebutuhan biasanya diberi pakan tambahan berupa pakan konsentrat. Imbangan hijauan dan konsentrat menjadi penting mengingat suplai nutrien terutama protein dan energi (TDN) yang terkandung dari kedua jenis pakan tersebut menjadi tolok ukur keberhasilan dalam mencapai pertumbuhan yang maksimal. Namun demikian imbangan tersebut harus juga menghitung pula nilai ekonomi dari pakan yang diberikan agar pertumbuhan ruminansia tidak hanya maksimal namun juga optimal.

Di peternakan domba rakyat pemberian hijauan dan konsentrat memiliki imbangan yang berbeda-beda bergantung pada kemampuan peternak dalam membeli konsentrat serta periode pemeliharaannya. Imbangan $80 \%$ hijauan dan $20 \%$ konsentrat pada domba sering juga digunakan oleh peternak domba untuk memenuhi kebutuhan nutrient dan energi bagi ternaknya, meskipun imbangan ini belum memberikan pertumbuhan yang maksimal. Menurut Yunasri, Eka \& Nuzul (2013) bahwa imbangan $80 \%$ hijauan dan $20 \%$ konsentrat masih memberikan daya toleransi ternak dan mampu mendukung aktivitas yang terjadi di rumen dalam mencerna pakan.

\section{METODE PENELITIAN}

Penelitian menggunakan 8 domba Garut jantan umur 13-16 bulan yang terdapat di UPTD Balai Pengembangan dan Pembibitan Domba dan Kambing Margawati Kabupaten Garut. Domba tersebut dipelihara selama 12 minggu untuk masa penelitian dan diberi ransum percobaan terdiri atas $80 \%$ rumput Gajah cv Mott dan 20\% konsentrat. Kandungan nutrien ransum percobaan yang digunakan disajikan pada Tabel 1. Kemudian diukur pertambahan bobot badannya yang dilakukan setiap 1 minggu sekali selama periode pengamatan. 
Tabel 1. Nutrien bahan pakan dan ransum percobaan

\begin{tabular}{lccc}
\hline \multicolumn{1}{c}{ Nutrien } & $\begin{array}{c}\text { Rumput Gajah } \\
\text { Taiwan (R) }\end{array}$ & Konsentrat $(\mathrm{K})$ & $\begin{array}{c}\text { Ransum } \\
(80 \% \mathrm{R}: 20 \% \mathrm{~K})\end{array}$ \\
\hline Air (\%) & 68,89 & 6,83 & 56,48 \\
Abu (\%) & 11,53 & 11,75 & 11,57 \\
Protein kasar (\%) & 9,51 & 13,08 & 10,22 \\
Lemak kasar (\%) & 4,17 & 10,97 & 5,53 \\
Serat kasar (\%) & 34,19 & 17,81 & 30,91 \\
Bahan ekstrak tanpa & 42,61 & 44,00 & 42,89 \\
nitrogen/BETN (\%) & & & 55,86 \\
Total digestible & 53,39 & 65,74 & \\
nutrient/TDN $(\%)$ & & & \\
\hline Kenterang
\end{tabular}

Keterangan: Berdasarkan 100\% bahan kering

Data yang diperoleh dianalisa dengan menggunakan aplikasi Curve expert. Model persamaan non linear yang digunakan berupa model Logistic, Gompertz, Richard, Morgan Mercer Floden (MMF), Polynomial Fit, Sinusoidal Fit, dan Reciprocal Quadratic. Penentuan model kurva terbaik

Tabel 2. Model matematika kurva non linear

\begin{tabular}{lc}
\hline \multicolumn{1}{c}{ Model } & Persamaan \\
\hline Gompertz & $y=a \times e^{-e^{b-c x}}$ \\
Logistic & $y=\frac{a}{1+b \times \frac{a}{a} e^{(-c x)}}$ \\
Richards & $y=\frac{\left(1+e((b-c x))^{\frac{1}{d}}\right.}{\left(1+c x^{d}\right.}$ \\
Morgan Mercer Floden (MMF) & $y=\frac{a b+x^{d}}{b+c x^{2}+d x^{3}}$ \\
Polynomial Fit & $y=a+b x+c+c o s(c x+d)$ \\
Sinusoidal Fit & $y=a+b \cos (c)$ \\
Reciprocal Quadratic & $y=\frac{1}{a+b x+c x^{2}}$
\end{tabular}

Keterangan: $\mathrm{Y}=$ Parameter yang diamati, $a=$ Konstanta, $b=$ Nilai skala parameter (konstanta integrasi), $\mathrm{e}=$ Bilangan natural $(\mathrm{e}=2,718282), \mathrm{x}=$ Waktu pengamatan, $c=$ Laju pertambahan bobot badan, $d=$ Parameter yang menentukan titik belok (-1 hingga 1$)$

\section{HASIL DAN PEMBAHASAN}

\section{Kons umsi Rans um}

Konsumsi ransum Domba Garut jantan umur 13-16 bulan pada imbangan $80 \%$ hijauan dan $20 \%$ konsentrat disajikan pada Tabel 3. Rataan konsumsi bahan kering (BK) Domba Garut jantan pada hasil penelitian ini sebesar 1078 g/ekor/hari dilihat dari nilai koefisien determinasi $\left(\mathrm{R}^{2}\right)$ terbesar dan nilai standar error (SE) terkecil pada persamaan regresinya (Salman, Noor, Saefuddin \& Talib, 2012). Adapun model matematik kurva yang digunakan pada penelitian ini dapat dilihat pada Tabel 2. 
dan konsentrat 26,30\% memiliki konsumsi BK sebesar 646 g/ekor/hari Nurjannah, Ayuningsih, Henaman \& Susilawati (2019) menambahkan bahwa rata-rata konsumsi BK Domba Garut jantan yang diberi ransum dan Indigofera memiliki konsumsi BK berkisar antara 429,94-508,80 g/ekor/hari
Berdasarkan dari dua penelitian tersebut, konsumsi BK ransum Domba Garut hasil penelitian dianggap baik. Konsumsi pakan dipengaruhi oleh jenis pakan yang diberikan, kondisi fisiologis ternak, dan kondisi lingkungan ternak yang dipelihara (Astuti, Erwanto \& Purnama, 2015).

Tabel 3. Rataan konsumsi bahan kering domba Garut umur 13-16 bulan

\begin{tabular}{cc}
\hline Minggu ke- & Rataan Konsumsi Bahan Kering (g/ekor/hari) \\
\hline 1 & 1341 \\
2 & 1282 \\
3 & 1267 \\
4 & 1275 \\
5 & 1201 \\
6 & 1070 \\
7 & 963 \\
8 & 921 \\
9 & 899 \\
10 & 879 \\
11 & 931 \\
12 & 903 \\
\hline Rataan & 1078 \\
\hline
\end{tabular}

Supratman, Setyatwan, Budinuryanto, Fitriani \& Ramdani (2016) menyatakan bahwa peningkatan imbangan konsentrat terhadap hijauan akan meningkatkan konsumsi BK. Hal ini menunjukan bahwa konsentrat yang digunakan dalam penelitian memiliki palatabilitas dan kandungan $\mathrm{BK}$ yang tinggi dibandingkan dengan hijauan. Palatabilitas pakan akan menentukan jumlah pakan yang dimakan, ternak akan memilih pakan sesuai dengan kebutuhan nutrien dan karakteristik dari pakan itu sendiri. Ternak domba merupakan ternak yang pemilih, domba cenderung memilih memakan bagian daun dibandingkan dengan bagian batang karena nutrien dan daya cerna lebih tinggi (Sudarmono \& Sugeng, 2011).

Nilai bobot badan digunakan sebagai salah satu kriteria untuk menilai perkembangan dari suatu ternak dan dalam mengukur nilai ekonominya. Bobot badan Domba Garut Jantan umur 13-16 bulan yang diberi imbangan pakan $80 \%$ hijauan dan $20 \%$ konsentrat berdasarkan hasil penelitian disajikan pada Tabel 2. Berdasarkan hasil tersebut didapatkan Domba Garut yang diberi ransum dengan imbangan $80 \%$ hijauan dan $20 \%$ konsentrat memiliki rataan bobot akhir sebesar 30,02 $\pm 2,29 \mathrm{~kg}$. Hasil tersebut kbih kecil dari SNI Nomor 7523 (2015) yang menyatakan bahwa bobot badan Domba Garut jantan umur 12-18 bulan sebesar $33 \mathrm{~kg}$. Menurut Supratman, Setyatwan, Budinuryanto, Fitriani, \& Ramdani (2016) pemberian pakan hijauan yang tinggi pada ransum domba menyebabkan pertambahan bobot badan domba kurang maksimal jika dibandingkan dengan domba yang diberi imbangan konsentrat yang lebih tinggi. 
Tabel 4. Rataan bobot badan mingguan domba Garut umur 13-16 bulan

\begin{tabular}{cc}
\hline Minggu ke- & Rataan Bobot Badan Mingguan (Kg/ekor/hari) \\
\hline 0 & 25,48 \\
1 & 25,71 \\
2 & 25,96 \\
3 & 26,24 \\
4 & 26,54 \\
5 & 26,88 \\
6 & 27,21 \\
7 & 27,69 \\
8 & 28,18 \\
9 & 28,76 \\
10 & 29,36 \\
11 & 29,72 \\
12 & 30,02 \\
\hline
\end{tabular}

Rataan bobot badan Domba Garut penelitian masih di bawah standar SNI, hal ini dikarenakan pemberian hijauan lebih banyak dibandingkan dengan konsentrat. Menurut Purbowati (2009) pemberian konsentrat yang lebih tinggi dalam pakan dapat meningkatkan pertambahan bobot badan yang lebih signifikan, hal ini dikarenakan konsentrat memiliki nilai gizi yang lebih tinggi dan mudah dicerna. Yamashita, Rachmat, Tarmidi, Ayuningsih \& Hernaman (2018) menyatakan bahwa faktor yang mempengaruhi daya cerna pakan salah satunya adalah kandungan serat kasar. Kandungan serat kasar yang tinggi akan menyebabkan kerja enzim pencernaan kurang optimal, sehingga menurunkan kecernaan pakan. Pemberian hijauan pada ternak akan meningkatkan bulky atau voluminous, serta gerak laju digesti yang lebih lama di dalam rumen (Astuti, Erwanto \& Purnama, 2015).

\section{Kurva Pertambahan Bobot Badan}

Pertambahan bobot badan (PBBH) merupakan salah satu indikator untuk mengukur pertumbuhan seekor ternak. Pertambahan bobot badan harian $(\mathrm{PBBH})$ Domba Garut pada penelitian ini dilakukan dengan menghitung bobot badan domba setiap minggu dibagi 7 hari. Berdasarkan hasil penelitian, disajikan $\mathrm{PBBH}$ Domba Garut jantan pada imbangan $80 \%$ hijauan dan $20 \%$ konsentrat pada Tabel 5.

Tabel 5. Rataan pertambahan bobot badan harian Domba Garut jantan umur 13-16 bulan

\begin{tabular}{cc}
\hline Minggu ke- & Rataan Pertambahan Bobot Badan Harian (g/ekor/hari) \\
\hline 1 & 32,14 \\
2 & 35,71 \\
3 & 41,07 \\
4 & 42,85 \\
5 & 47,32 \\
6 & 48,21 \\
7 & 67,85 \\
8 & 70,53 \\
9 & 83,03 \\
10 & 84,82 \\
11 & 51,78 \\
12 & 42,85 \\
\hline Rataan & 54,02 \\
\hline
\end{tabular}


Pertambahan bobot badan harian (PBBH) Domba Garut hasil penelitian memiliki rataan kenaikan $\mathrm{PBBH}$ sebesar 54,02 gram/ekor/hari Hasil tersebut lebih besar dibandingkan dengan hasil penelitian Prawoto, Lestari \& Purbowati (2001) bahwa PBBH Domba Priangan jantan sebesar 43,25 gram/ekor/hari Hasil penelitian Sihotang, Sudrajat \& Dihansih (2012) bahwa Domba Lokal yang diberi pakan hijauan 70\% memiliki PBBH sebesar 43,95 gram/ekor/hari. Berdasarkan dari dua penelitian tersebut PBBH Domba Garut jantan pada imbangan hijauan $80 \%$ dan konsentrat $20 \%$ dikatakan masih baik.
Pertambahan bobot badan harian $(\mathrm{PBBH})$ akan meningkat jika ternak diberi pakan dengan kualitas dan kuantitas yang baik, sehingga pemberian pakan bagi ternak mampu mencukupi kebutuhan pokok dan produksinya. Kualitas ransum yang digunakan pada penelitian ini memiliki kualitas yang cukup baik karena memiliki palatabilitas yang baik serta mampu meningkatkan PBBH Domba Garut jantan. Nurjannah, Ayuningsih, Henaman \& Susilawati (2019) menyatakan bahwa ransum yang memiliki kualitas dan nilai palatabilitas yang tinggi dapat mempercepat laju pertumbuhan dan pertambahan bobot badan.

Tabel 6. Hasil analisis Kurva pertambahan bobot badan domba Garut Jantan Umur 13-16 bulan yang diberi ransum $80 \%$ hijauan dan $20 \%$ konsentrat

\begin{tabular}{llccc}
\hline No & Model Kurva & Persamaan & SE & $\mathrm{R}^{2}$ \\
\hline 1 & Polynomial Fit & $y=2,61+9,53 \mathrm{X}-3,50 \mathrm{X}^{2}+0,676 \mathrm{X}^{3}-0,03 \mathrm{X}^{4}$ & 7,27 & 0,94 \\
2 & Sinusoidal Fit & $y=5,39+2,19 \cos (5,20 \mathrm{X}+1,81)$ & 9,19 & 0,90 \\
3 & Reciprocal Quadratic & $y=\frac{1}{4,9-8,37 X+4,9 x^{2}}$ & 9,47 & 0,87 \\
& & & \\
\hline
\end{tabular}

Kurva pertambahan bobot badan mingguan Domba Garut penelitian menggambarkan peningkatan $\mathrm{PBBH}$ setiap minggunya. Bobot badan Domba Garut yang terus meningkat dapat dilihat dari bentuk kurva pertambahan bobot badan seperti ditujkan pada Gambar 1. Keakuratan model kurva yang digunakan diamati berdasarkan nilai koefisien determinasi $\left(\mathrm{R}^{2}\right)$ dan standar error (SE). Persamaan regresi non linear serta Nilai koefisien determinasi $\left(\mathrm{R}^{2}\right)$ dan standar eror (SE) hasil analisa disajikan dalam Tabel 6.
Nilai koefisien determinasi $\left(\mathrm{R}^{2}\right)$ berdasarkan model polynomial, model sinusoidal dan model reciprocal quadratic adalah 0,94, 0,90, dan 0,87. Nilai standar error berdasarkan tiga model tersebut berturut-turut adalah 7,27, 9,19, dan 9,47. Model tersebut merupakan tiga model persamaan regresi non linear yang terbaik dibandingkan dengan model persamaan regresi non linear yang lainnya dilihat dari rangking terbesar yang memiliki nilai $R^{2}$ yang besar dengan nilai SE yang kecil. 


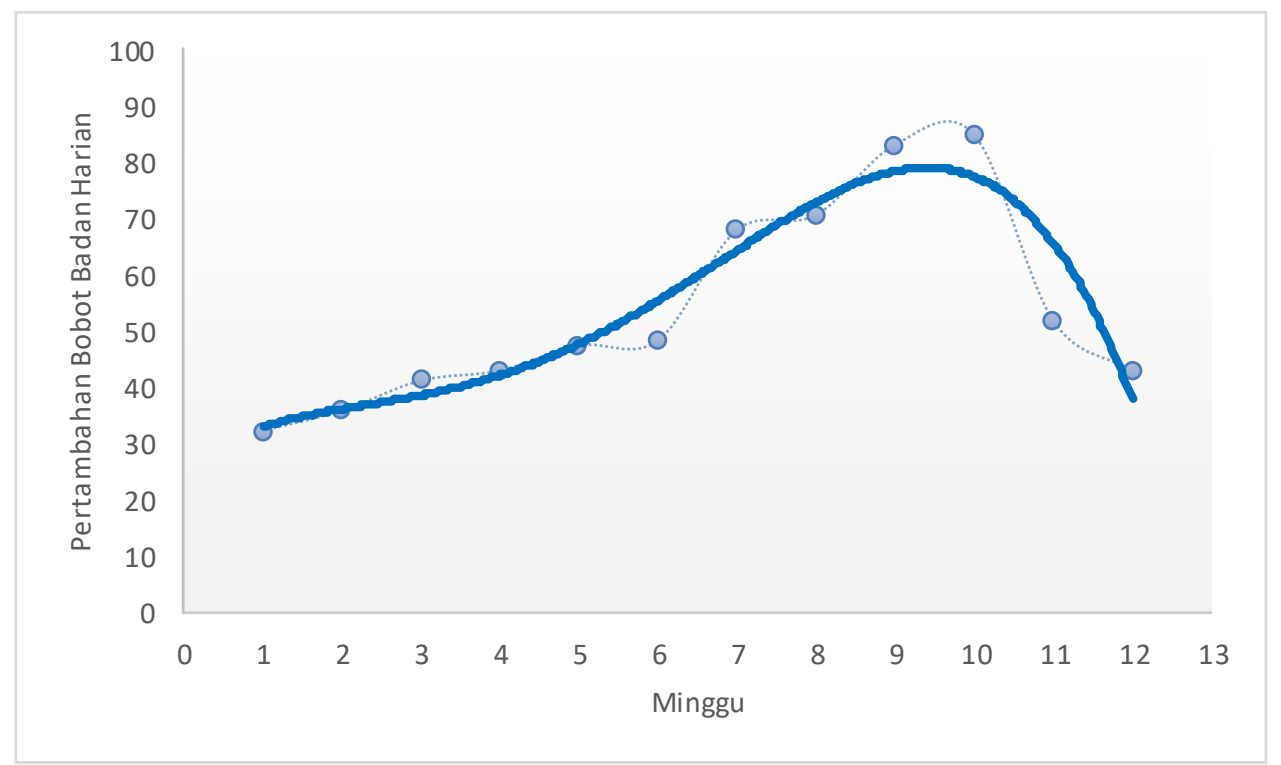

Gambar 1. Kurva Pertambahan Bobot Badan Harian Domba Garut Jantan Umur 13-16 bulan pada Imbangan $80 \%$ Hijauan dan $20 \%$ Konsentrat

Kurva polynomial derajat 4 (Tabel 6) memiliki nilai koefisien determinasi $\left(\mathrm{R}^{2}\right)$ paling besar dengan standar eror (SE) yang paling kecil, sehingga model kurva polynomial derajat 4 dapat mewakili sampel data penelitian. Adapun kurva model tersebut ditunjukan pada Gambar 1. Pada model kurva tersebut menggambarkan adanya kenaikan PBBH sampai minggu ke-10, setelah itu menurun kembali. Kondisi ini domba yang digunakan berumur 13-16 bulan, dimana masa pubertasnya sudah terlewati. Rusdiana \& Adiati (2020), menyatakan bahwa proses pertumbuhan yang cepat pada domba akan terjadi pada awal kehidupannya sampai mengalami pubertas, lebih lanjut pertumbuhan melambat pada saat domba mencapai dewasa tubuh.

\section{KESIMPULAN}

Kurva pertambahan bobot badan domba Garut jantan umur 13-16 bulan yang diberi imbangan $80 \%$ hijuan dan $20 \%$ konsentrat mengalami peningkatan sampai pemeliharaan minggu ke-10 kemudian menurun dan model kurva terbaik untuk pertambahan bobot badan yaitu model
Polynomial dengan persamaan $y=$ $2,61+9,53 X-3,50 X^{2}+0,676 X^{3}-0,03 X^{4} \quad$ serta memiliki nilai standar error (SE) 7,27 dan koefisien determinasi $\left(\mathrm{R}^{2}\right)$ 0,94.

\section{UCAPAN TERIMAKASIH}

Penelitian ini dilaksanakan di UPTD Balai Pengembangan Perbibitan Ternak Domba dan Kambing Margawati, Dinas Ketahan Pangan dan Peternakan Provinsi Jawa Barat, untuk itu tim penulis mengucapkan terimakasih atas fasilitas penelitian yang disediakan.

\section{DAFTAR PUSTAKA}

Anang, A., Dudi, Indrijani, H. \& Rahmat, D. 2013. Laporan Akhir Penelitian Uji Performance Domba Garut di UPTD BPPTD Margawati Garut Jawa Barat. Fakultas Peternakan Universitas Padjadjaran. Sumedang.

Astuti, A., Erwanto, \& Purnama, E.S. 2015. Pengaruh cara pemberian konsentrathijauan terhadap respon fisiologis dan performa sapi peranakan 
simmental. Jurnal Ilmiah Peternakan Terpadu 3(4), 202-206.

Ayuningsih, B., Hernaman, I. Ramdani, D \& Siswoyo. 2018. Pengaruh imbangan protein dan energi terhadap efisiensi penggunaan ransum pada domba garut betina. Jurnal Ilmiah Peternakan Terpadu. 6 (1), 97-100.

Haya, A.K., Anang, A. \& Heriyadi, D. 2020. Pendugaan parameter genetik performa prasapih domba Garut di UPTD-BPPTDK Margawati Garut. Majalah Ilmiah Peternakan 23 (1), 16

Heriyadi, D. \& Surya, B.S. 2004. Sertifikasi Bibit Domba Garut Tahap II. Laporan Penelitian. Laporan Penelitian Kerjasama Dinas Peternakan Provinsi Jawa Barat dengan Himpunan Peternak Domba dan Kambing Indonesia (HPDKI) Jawa Barat. Bandung.

Kusnadi, H., Wahyuni, A.W. \& Zul, E. 2015. Teknologi Pengawetan Hijauan Makanan Ternak (HMT) dan Limbah Pertanian. Balai Pengkajian Teknologi Bengkulu. Bengkulu. 1517.

National Research Council. 2006. Nutrient Requirements of Small Ruminant (Sheep, Goats, Cervids, and New World Camelids). National Academic Press. Washington DC. National Academy Press.

Nurjannah, S., Ayuningsih, B., Henaman, I. \& Susilawati, I. 2019. Pengaruh kaliandra (Calliandara calothyrsus), Indigofera $s p$. dan campurannya dalam ransum sebagai pengganti konsentrat terhadap produktivitas domba garut jantan. Jurnal Ilmial Peternakan Terpadu 7 (3), 294-298.
Prawoto, J.A., Lestari, C.M.S. \& Purbowati, E. 2001. Keragaan dan kinerja produksi domba lokal yang dipelihara secara intensif dengan memanfaatkan ampas tahu sebagai bahan pakan campuran. Jurnal Pengembangan Peternakan Tropis. 277-280.

Purbowati E. 2009. Usaha Penggemukan Domba. Penebar Swadaya. Jakarta. 42-48.

Putra, W.P.B., Sumadi, K., Hartatik, T. \& Saumar, H. 2018. Pendugaan model kurva pertumbuhan berat badan pada sapi Aceh (Bos indicus). Jurnal Ilmu dan Teknologi Peternakan Indonesia 4(1), 166-171.

Salman, L.B., Noor, R.R., Saefuddin, A. \& Talib, C. 2012. Comparison on accuracy of logistic, gompertz and von bertalanffy models in predicting growth of new born calf until first mating of holstein Friesian heifers. $J$. Indonesian Trop. Anim. Agric. 37(3), 151-160.

Sihotang, A., Sudrajat, D. \& Dihansih, E. 2012. Performa pertumbuhan domba lokal jantan yang mendapat pakan tepung kulit kopi. Jurnal Pertanian 3 (2), 84-88.

Sudarmono, A.S \& Sugeng, B.Y. 2011. Beternak Domba. Penebar Swadaya. Jakarta. 19-24.

Supratman, H., Setyatwan, H., Budinuryanto, D.C., Fitriani, A. \& Ramdani, D. 2016. Pengaruh imbangan hijauan dan konsentrat pakan komplit terhadap konsumsi, pertambahan bobot badan, dan konversi pakan domba. Jurnal Ilmu Ternak. 16 (2), 99-100. 
Urfa, S., Indrijani, H. \& Tanwiriah, W. 2017. Model kurva pertumbuhan ayam kampung unggul balitnak (KUB) umur 0-12 minggu. Jurnal Ilmu Ternak, 17 (1), 59-66

Yamashita, S.A., Rachmat, R.D., Tarmidi, A.R., Ayuningsih, B. \& Hernaman, I. 2019. Kecernaan ransum yang mengandung limbah roti pada domba.
Jurnal Ilmu dan Teknologi Peternakan Tropis, 7(1), 47-51

Yunasri, U., Eka M.S. \& Nuzul, F. 2013. Evaluasi pertambahan bobot badan sapi aceh jantan yang diberi imbangan antara hijauan dan konsentrat di balai pembibitn ternak unggul indrapuri. Jurnal Agripet 1 (2), 41- 46 